\title{
"Ayurveda formulation AYUSH 64 in asymptomatic and mild COVID 19 infection-A prospective, open label Clinical Study"
}

\section{Authors:}

1. Dr Manoj Shamkumar, Associate Professor, Department of Panchakarma, Ayurveda and Unani Tibbia College and Hospital, Karol Bagh, New Delhi.

2. Dr. Shivshankar Rajput, Research Officer (Ayurveda), c

3. Dr Babita Yadav, Research Officer (Ayurveda), Central Council for Research in Ayurvedic Sciences, New Delhi

4. Dr Sujata Rajan, Associate Professor, Department of Kriya Sharir, Ayurveda and Unani Tibbia College and Hospital, Karol Bagh, New Delhi.

5. Dr. Nitin Jindal, Assistant Professor, Department of Panchakarma, Ayurveda and Unani Tibbia College and Hospital, Karol Bagh, New Delhi.

6. Dr Lalita Sharma, Research Officer (Ayurveda), Central Council for Research in Ayurvedic Sciences, New Delhi

7. Dr Rakesh Kumar Rana, Statistics Officer, Central Council for Research in Ayurvedic Sciences, New Delhi

8. Dr Richa Singhal, Senior Statistics Assistant, Central Council for Research in Ayurvedic Sciences, New Delhi

9. Dr Shruti Khanduri, Research Officer (Ayurveda), Central Council for Research in Ayurvedic Sciences, New Delhi

10. Dr B.S. Sharma, Research Officer (Ayurveda), Central Council for Research in Ayurvedic Sciences, New Delhi

11. Dr B.C.S Rao, Assistant Director (Ayurveda), Central Council for Research in Ayurvedic Sciences, New Delhi

12. Dr N. Srikanth, Director General Additional Charge, Central Council for Research in Ayurvedic Sciences, New Delhi

13. Dr Bharti, Director, Central Council for Research in Ayurvedic Sciences, New Delhi

14. Prof. Vaidya K.S. Dhiman, Professor, Department of Shalakya Tantra, Faculty of Ayurveda, Institute of Medical Sciences, Banaras Hindu University, Varanasi; Former Director General, Central Council for Research in Ayurvedic Sciences, New Delhi

15. Dr R.K. Manchanda, Director (AYUSH) Government of NCT Delhi 


\title{
Ayurveda formulation AYUSH 64 in asymptomatic and mild COVID 19 infection- A prospective, open label Clinical Study
}

\begin{abstract}
Background

COVID 19 pandemic has evolved as a unique unprecedented global health crisis that has affected severely the economies and daily lives of people. Despite the diligent worldwide efforts to contain it, there is an exponential rise in cases. Associated serious morbidity and mortality has continued the efforts towards a clinically proven prophylaxis and therapeutic strategy. In the absence of any effective approved treatment, drug repurposing of available drugs are underway across the globe for treating COVID 19 patients. AYUSH 64 is an antimalarial Ayurveda formulation repurposed in COVID 19 management due to its proven efficacy in malaria and influenza like illness.
\end{abstract}

Trial Design: This was a prospective, open-label, single-arm, pilot study conducted at Ayurveda and Unani Tibbia College(A\&U Tibbia ) and Hospital, Designated COVID19 Health Center under Govt. of NCT of Delhi.

Objective: The primary objective of the study was to assess the efficacy of AYUSH 64 in the management of asymptomatic, mild to moderate COVID-19 cases .However the secondary objectives were to assess clinical safety and to describe the clinical profile of COVID-19 with special reference to early symptoms, severity of disease, complications, course of disease, diagnostic investigations, biochemical \& imaging abnormalities and patterns of clinical recovery.

\section{Methods:}

The study was conducted on 40 patients out of which maximum were asymptomatic and mild COVID-19 cases of either sex aged above 18 years admitted in the hospital with positive naso-pharyngeal swab test for SARS-CoV-2 (RT-PCR ) or Rapid antigen test. Ayush- 64 tablets in the dose of two tablets $(500 \mathrm{mg})$ thrice a day after food with warm water was given to the participants for the period of 7 to 14 days but once the patient got RtPCR negative ,medicine was discontinued. The primary outcome of the 
study was negative status of SARS-CoV-2 on nasal or throat swab after 07 days or 14 days of intervention in a 2-day continuous real time RT-PCR test and changes in liver enzymes \& renal functions. The secondary outcome of the study included the mean time (days) for clinical recovery as per clinical recovery criteria defined, number of symptomatic patients showing clinical recovery and improvement in selected laboratory parameters:, differential and total leukocyte counts, acute phase reactants, serum IL-6, Serological Protective Antibody Assay (IgE , IgM and IgG).

\section{Results}

Out of 40 participants who were enrolled in the study, 36 (90\%) completed the trial. Out of 36 participants, 69.44\% participants after 07 days of AYUSH 64 intervention in the study became RT-PCR negative until $8^{\text {th }}$ day and the rest $30.55 \%$ participants completed the study in 14 days and they turned RT-PCR negative on 15th day. Out of 36 participants, 28 participants were symptomatic. $39.28 \%$ participants clinically recovered in 7 days of AYUSH-64 intervention and 53.5\% participants clinically recovered in 14 days. Mean time for clinical recovery was 7.04 days ( \pm 2.88 days standard deviation). No adverse drug reaction was found in any of the participants. Serious adverse event (SAE) was reported in two participants (5\%) just another day after enrolment in the study, which was not related, to the trial drug and the same was informed to the sponsor.

\section{Conclusion}

Among asymptomatic and mild COVID-19 cases, the repurposing of AYUSH 64 was found effecatious and quite safe to alleviate infection with significant clinical improvement within 14 days. Subsequent research on larger scale is warranted for statistically robust evidences in the treatment of COVID-19.

Trial Registration: CTRI/2020/05/025338- Clinical Trials Registry-India

Key words: Ayurveda, AYUSH 64, COVID-19, SARS-CoV-2 


\section{Introduction:}

The COVID-19 outbreak has been unprecedented since the cases were first reported in China in December 2019 and has affected 220 countries and territories around the world $^{1}$. COVID-19 has a wide range of symptoms reported ranging from mild symptoms to severe illness, which may appear 2-14 days after exposure to the virus. The symptoms include fever or chills, sore throat, shortness of breath or difficulty in breathing, cough, fatigue, headache and muscle or body aches, loss of taste or smell, nausea or vomiting, nasal congestion and diarrhoea ${ }^{2}$.

Individuals of any age are at risk for COVID 19 infection. However, the probability of severe COVID-19 disease is maximum in people aged above 60 years, or having chronic diseases. The incubation period of COVID-19 from the time of exposure is up to 14 days. The period of infectiousness, onset and viral shedding duration are not completely defined. Common laboratory findings of COVID-19 include lymphopenia, leukopenia, elevated levels of aminotransferase, D-dimer, C-reactive protein; lactate dehydrogenase and ferritin ${ }^{3}$.Molecular diagnostics of the viral genome is by Reverse transcription polymerase chain reaction (RT-PCR), chest x-ray or CT scan, and serology blood tests ${ }^{4}$.

Although many therapies have been proposed but no effective treatment to cure COVID-19 has been reported and mainly antiviral drugs and respiratory therapies are being used to treat the disease. With the number of COVID-19 cases surpassing every day, its socio-economic impact necessitates an urgent need for effective treatment modality. Developing new drug in a time-critical fashion is impractical seeing the immediate global challenge. Drug repurposing is an emerging strategy where existing medicines, having detailed information on their pharmacology, formulation and potential toxicity and tested safe in humans are redeployed to combat difficult-to-treat diseases $^{5}$.It confers reduction in risk failure where a failure rate of approximately $45 \%$ is mainly associated to safety or toxicity issues in drug discovery with an additional benefit of saving average drug development time up to 5-7 years. The therapeutic value of a drug is maximized and consequently the success rate increases ${ }^{6}$. Since repurposing is based upon previous research and development efforts, hence the drug repurposed 
could easily be ready for clinical trials quickly like Ayush 64 which was meant for Malaria \& flue like illness.

Besides hailing the immunity boosting measures of AYUSH systems of medicine in these pressing times, Government of India has backed their role in prevention and treatment of the COVID-19. Being an opportune time to evaluate the Ayurveda concepts of holistic approach towards disease management and its interventions for prevention and treatment of the disease, several initiatives have been implemented in addressing COVID 19 pandemic problem through clinical studies on AYUSH systems of medicine. One such initiative was taken by Central Council for Research in Ayurvedic Sciences, under Ministry of AYUSH, Govt. of India in which AYUSH 64 , a poly herbal drug (Table 1) developed for its anti-malarial activity through extensive safety and efficacy studies was repurposed in COVID 19 based on its antiviral, immunomodulator and antipyretic properties. AYUSH 64 is an anti-malarial drug found clinically effective in Plasmodium vivax, and P. falciparum malaria ${ }^{7,8}{ }^{9}$ but has also been found effective in fever of unknown aetiology and filarial lymphadenitis ${ }^{10,11,12}$.An experimental study on AYUSH 64 has shown it to be safe in a dose of $500 \mathrm{mg} / \mathrm{kg}$ body weight for a duration of 12 weeks ${ }^{13}$. Many of the clinical studies besides efficacy have reported that the formulation is safe without any adverse drug reaction or serious adverse events on parameters like Liver function test, Kidney function test ${ }^{14,15,16}$

As per a recent study on AYUSH 64, one-week intervention of AYUSH-64 in a dose of 3 gms/day helped to recover from Influenza like illness symptoms with reduced frequency of usage of acetaminophen and antihistaminic drug. The intervention was found safe and could be used in other viral infections with pyrexia for early recovery and better outcome ${ }^{17}$. At the same time in COVID Scenario, Council has conducted insilico study in collaboration with the National Institute of Nutrition, Hyderabad on AYUSH 64.The results showed that about 35 of its phyto-constituents have high binding affinity in COVID 19 virus ${ }^{18}$. This lead to repurposing AYUSH 64 in COVID19. 
COVID 19 resembles the symptoms of Vata Kaphaj Jvara or Sannipataj Jwara (pittanubandhi) as per the Ayurvedic Classics ${ }^{19}$. The trial drug AYUSH 64 is made of herbs Saptaparna (Alstonia scholaris) Katuki (Picrorhiza kurroa), Kiratatikta (Swertia Chirata) and Kuberaksha (Caesalpinia bonducella). The constituents used in the drug AYUSH-64 are Jwarghna (useful in fevers), ShwasaKaasaghna (useful in breathlessness, cough), Shothaghna (anti-inflammatory) and have anti-inflammatory and immunomodulatory activity ${ }^{20}$.

A pilot study on AYUSH 64 was specifically designed to determine an appropriate evidence-based treatment modality from Ayurveda. This pilot study intended to evaluate the efficacy and safety of AYUSH 64 in the management of mild to moderate cases of COVID-19.

\section{Methods:}

\section{Study Design:}

The study is a prospective, open-label, single-arm, pilot clinical trial in accordance with the principles of Declaration of Helsinki and National Ethical Guidelines for Biomedical and Health Research involving Human Participant, 2017 by Indian Council of Medical Research.

\section{Study Setting:}

This study has been conducted at Ayurvedic and Unani Tibbia College and Hospital, Designated COVID Health Center under Govt. of NCT of Delhi.

\section{Study Participants:}

COVID 19 cases with positive naso-pharyngeal swab test for SARS-CoV-2 on RT-PCR or Rapid antigen test fulfilling the selection criteria of the study and admitted to Ayurvedic and Unani Tibbia College and Hospital, Delhi were enrolled in the study. 


\section{Selection Criteria:}

The participants with the following inclusion criteria were included in the study after taking informed written consent:

\section{Inclusion criteria:}

Participants of either sex age above 18 to 60 years admitted at Ayurvedic and Unani Tibbia College and Hospital, Delhi with positive RT-PCR test or Rapid Antigen test for SARS-CoV-2 diagnosed as asymptomatic, mild* to moderate case** of COVID 19 as per the prevailing government guideline who were able to take oral medications and voluntarily signed the informed consent form for participation were included in the study.

*Mild COVID -19 : Patients with uncomplicated upper respiratory tract infection, may have mild symptoms such as fever, cough, sore throat, nasal congestion, malaise, headache Without shortness of breath or Hypoxia (normal saturation (Ref: 2 Revised guidelines for Home Isolation of very mild/asymptomatic COVID-19 cases (https://www.mohfw.gov.in/pdf/RevisedguidelinesforHomelsolationofmildasymptomaticCOVID19ca ses.pdf)

Moderate COVID 19: Pneumonia with no signs of severe disease Adults with presence of clinical features of dyspnea and or hypoxia, fever, cough, including SpO2 90 to $\leq 93 \%$ on room air, Respiratory Rate more or equal to 24 per minute. (Ref: 2 Revised guidelines for Home Isolation of very mild/asymptomatic COVID-19 cases (https://www.mohfw.gov.in/pdf/RevisedquidelinesforHomelsolationofmildasymptomaticCOVID19ca ses.pdf

\section{Exclusion Criteria:}

Participants with severe vomiting who could not take oral drugs, respiratory failure and requiring mechanical ventilation, in critical condition or ARDS or NIAD 8 -point ordinal score 2 Hospitalized, on invasive mechanical ventilation or extra corporeal membrane oxygenation or liver enzymes Alanine Transaminase (ALT) or Aspartate Transaminase $(\mathrm{AST})>2$ times the upper limit of normal, pregnant or lactating women 
or having any other condition which as per the investigator would jeopardize the outcome of the trial.

\section{Study Intervention:}

The study drug is a polyhedral Ayurveda formulation AYUSH 64 developed and patented by Central Council for Research in Ayurvedic Sciences, New Delhi (Table 1) for antimalarial activity and repurposed as trial drug against mild to moderate cases of COVID 19 on the basis of its antiviral, immuno-modulator and antipyretic properties. Central Council of Research in Ayurvedic Sciences procured the trial drug from Indian Medicines Pharmaceutical Corporation Limited, Almora, Uttarakhand. The quality control and safety parameters of the formulation and its ingredients was complied with API limits/ In-house limits. The trial drug was given to the participants in the dose of 2 Tablets (500mg each) thrice daily with warm water after food i.e $3 \mathrm{gm} /$ day for 7 days or 14 days. The duration of therapy depended upon the COVID -19 test done on $8^{\text {th }}$ day and $9^{\text {th }}$ day consecutive days. If the test was positive, the trial drug was continued for the next seven days, and if the test was negative on two consecutive days, treatment was discontinued. Participant with drug compliance more than or equal to $80 \%$ were continued in the study. The compliance was assessed at each follow-up.

\section{Sample Size:}

The study was conducted as a pilot study with sample size as 30 participants. Assuming attrition rate as $25 \%$ the sample size of 40 was fixed for the study ${ }^{21}$.

\section{Data Variables:}

Data variables recorded in the study included demographic details like age, gender, marital status, educational status, occupation, socio-economic status, habitat, religion ; vital signs viz. temperature, respiration rate, pulse rate, blood pressure- systolic \& diastolic, SPO2; clinical signs and symptoms such as fever at evaluation, history of fever, cough, breathlessness, sore throat, sputum, nausea, body ache (muscle pain), abdominal pain, vomiting, nasal discharge (nasal congestion), chest pain, anorexia, headache, wheeze, nasal flaring, stridor, crepitation, lower chest in drawing and accessory muscle use; laboratory investigations namely Haematology, Absolute 
lymphocyte Count, ESR, Blood Sugar : Fasting,HbA1c,Renal Function Test, Liver Function Test, Hs-CRP,IL-6,Ig-E,Ig-G,Ig-M and Urine Pregnancy Test, previous medication data, current medication data, comorbidity, travel \& exposure history i.e history of travel to overseas (COVID affected areas), travel / residence in COVID hotspots/ endemic areas, workplace exposure to COVID 19 cases and Direct / indirect Contact with COVID 19 cases (Except workplace exposure) The participants were also assessed for Ayurvedic parameters of fever namely laziness, watering of eyes, burning sensation in eyes, excessive yawning, heaviness in body, exhaustion without exertion, exhaustion with minimal exertion, fatigue, frequently changing affection and aversions for sound, heat, sunlight, wind, water etc, no desire for food, indigestion, tastelessness, depletion in strength, feeling fatigued, depletion of skin lustre, slight change in behaviour, agitated eyes, excessive sleep, restlessness, bending of body/feeling as if muscles and body are contracting, tremors, Giddiness/ vertigo, excessive and irrelevant talking, insomnia, horripilation, hyperaesthesia teeth or tingling in teeth, weakness, generalized body ache, slowness in activities], taking comparatively longer time for a routine work, inability to do regular functions, difficulty in deglutition/ingestion of food, aversion for sweets and sudden affection for sour, salty and pungent tastes.

\section{Outcome:}

\section{Primary Outcome measures:}

Primary outcome measures included negative status of SARS-CoV-2 on nasal or throat swab after 07 days or 14 days of intervention in a 2-day continuous real time RTPCR test

\section{Secondary Outcome measures:}

Mean time (days) for clinical recovery as per clinical recovery criteria defined, number of symptomatic patients showing clinical recovery [time frame: 7th day, 14th day if RTPCR positive-on $8^{\text {th }}$ or $9^{\text {th }}$ day] and improvement in selected laboratory parameters; differential and total leukocyte counts, acute phase reactants, serum IL-6, Serological Protective Antibody Assay (IgE , IgM and $\operatorname{IgG}$ ) assessed at $8^{\text {th }}$ or $15^{\text {th }}$ day time frame were the secondary outcome measures. The clinical recovery was defined as normal 
forehead temperature by thermal scanner, absence of cough (infrequent, short episodic, non-wheezy, relieved by minimal or no medication, not interfering with routine speech and not related to lying in bed, mild sore throat or nasal congestion), absence of breathlessness on routine daily self-care chore or respiratory rate less than 30 breaths per minute without any supplemental oxygen, normalization of $\mathrm{SpO} 2$ by standard peripheral oximetry device (above 95\%), recovery sustained for at least 48 hours under physician observation and absence of any other symptom/sign attributed to COVID-19 illness which were assessed on $7^{\text {th }}$ day and/or $14^{\text {th }}$ day from baseline. and changes in the safety parameters viz liver and renal function assessed on 8th day if the rtPCR was negative and or 15 th day.

\section{Statistical Analysis:}

The data has been analysed in two subgroups. Subgroup I for the participant who became RT-PCR negative for SARS-CoV-2 on nasal or throat swab after 07 days of intervention in a 2 day continuous real time RT-PCR test and subgroup II for the participants who became RT-PCR negative after 14 days of intervention in a 2 day continuous real time RT-PCR test. The data was analysed through Statistical package for Social Sciences (SPSS) version 15. The data on continuous variables are expressed as the mean \pm standard deviation / Median (Min-Max) and categorical variables are expressed as numbers and percentages. A $p$ value of less than 0.05 has been considered as significant. The assessment parameters have been compared for the participants who continued until $8^{\text {th }}$ day with baseline by using paired sample $t$ test or Wilcoxon signed rank test for data not distributed normally. The assessment parameters of the participants who continued in the study till $15^{\text {th }}$ day was compared at baseline, $8^{\text {th }}$ and $15^{\text {th }}$ day using Repeated Measures ANOVA/ Friedman test.

\section{Result:}

Total 46 COVID 19 cases admitted at Ayurvedic and Unani Tibbia College and Hospital, Designated COVID Health Centre under Govt. of NCT of Delhi were screened on the basis of inclusion criteria, out of which 40 participants fulfilling the 
inclusion criteria were enrolled in the study. Out of 40 participants enrolled, 04 participants were dropped out from the study as 02 discontinued the treatment while Serious Adverse Event (SAE) was reported in 02 participants who were referred to higher centre. Hence, outcome assessment was done on 36 participants. Among 36 participants, 08 participants were asymptomatic and 28 participants were mild COVID 19 cases. The CONSORT diagram of Study participants is shown in fig. 1.

All participants were found to be in the age group of 18-48 years with a mean age of $28.80 \pm 8.94$. Among them male participants were 28 (78.4\%) and female participants were 08 (21.6\%). 59.5\% participants were unmarried. In education status, maximum number of participants were graduate $12(32.4 \%)$. Maximum numbers of participants have fieldwork $16(43.2 \%)$ followed by $9(24.3 \%)$ participants involved in field work with physical labour. Among the total participants, 20 (56.8\%) were above the poverty line. The majority of the participants $22(62.2 \%)$ were from urban area followed by rural $03(29.7 \%)$ area. 02 (5.55 \%) participants had Hypertension as Comorbidity condition. The participants who had history of travel / residence in COVID hotspots/ endemic areas were 13 (36.1\%), workplace exposure to COVID 19 cases were $18(50.0 \%)$ and remaining COVID 19 cases informed that they have no direct contact with COVID patient (Table 2.)

Total 25 participants were found to be RT-PCR negative on $9^{\text {th }}$ day confirmed by two consecutive RT-PCR tests on $8^{\text {th }}$ and $9^{\text {th }}$ day and were considered in Subgroup I. Out of these 25 participants, 20 participants were symptomatic. The analysis of the clinical assessment data of symptomatic cases showed that symptoms like fever, breathlessness, sputum, nausea, abdominal pain and chest pain and Ayurveda parameters of Jawara like watering of eyes, burning sensation in eyes, exhaustion without exertion, indigestion, depletion in strength, depletion of skin lustre, slight change in behaviour, agitated eyes, excessive sleep, bending of body/feeling as if muscles and body are contracting, slowness in activities, taking comparatively longer duration for a routine work, inability to do regular functions, difficulty in deglutition/ingestion of food, aversion for sweets and sudden affection for sour, salty and pungent tastes were absent on $7^{\text {th }}$ day. The symptoms like cough persisted in 7 
$(35 \%)$, sore throat $3(15 \%)$, body ache $2(10.0 \%)$, nasal discharge $2(10.0 \%)$, anorexia 1 (5.0\%), vomiting 1 (5.0\%), headache 4 (20.0\%), laziness $3(12.0 \%)$, excessive yawning $2(8.0 \%)$, heaviness in body $3(12.0 \%)$, exhaustion with minimal exertion 2 $(8.0 \%)$, fatigue $8(32.0 \%)$, frequently changing affection and aversions for sound, heat, sunlight, wind, water etc, 1 (4.0\%) no desire for food 1 (4.0\%), tastelessness 1 (4.0\%), feeling fatigued $1(4.0 \%)$, restlessness 1 (4.0\%), Giddiness/ vertigo 1 (4.0\%), insomnia $1(4.0 \%)$, weakness $4(16.0 \%)$ and generalized body ache $4(16.0 \%)$ on $7^{\text {th }}$ day.

The other 11 participants who were found to be RT-PCR positive had completed the trial by $14^{\text {th }}$ day and were found to be RT-PCR negative in two consecutive RTPCR test done on $15^{\text {th }}$ and $16^{\text {th }}$ day. The data of these 11 participants was considered under Subgroup II for analysis. Out of the 11 participants, 08 participants were symptomatic. All the sign and symptoms at baseline were resolved in the participants except cough which was persisted in one case only .The percentage of relief in sign and symptoms may be seen in Table $3 \&$ Table 4 .as the tables are reflecting the details of presence of symptoms only in few cases.

Out of 28 participants who were symptomatic, mean time for clinical recovery was 7.04 days \pm 2.88 days.. The number of participants who clinically recovered till $7^{\text {th }}$ day were $11(39.2 \%)$ and the number of participants who clinically recovered till $14^{\text {th }}$ day were $15(53.5 \%)$. (Table 5).

Reduction in the levels of Hs-CRP, IgG and Ig M was observed in Subgroup I, though it was statistically insignificant. Reduction in levels of Hs-CRP, IL-6, IgE and IgM was observed in Subgroup II which was statistically insignificant. There was statistically insignificant increase in level of IgG from mean value 1615.04to 1635.73 on $15^{\text {th }}$ day in subgroup II. (Table 6)

Invasive or non-invasive oxygen therapy was not required during the intervention period for any of the participants who completed the trial. Oxygen therapy was given to one of the participant who was withdrawn from the trial due to SAE on $2^{\text {nd }}$ day of enrolment in the study and referred to higher health centre. 
The haematological tests, liver and renal function tests were found within the normal limits at the baseline and during the intervention period in the study. Statistically insignificant increase in haematological parameters within normal range was observed in Subgroup I and II (Table 6). Statistically significant reduction in level of Total protein ( $\mathrm{p}$ value 0.015 ) and Serum Globulin ( $\mathrm{p}$ value 0.043) was observed in Subgroup I. Reduction in levels of other laboratory parameters of liver and kidney function tests was also observed which was statistically insignificant in Subgroup I. Reduction in laboratory parameters of liver and kidney function test was observed in Subgroup II except SGPT from mean value 37.73 at baseline to 43.36 on $15^{\text {th }}$ day and Serum Alkaline phosphate from mean value 112.00 at baseline to 120.45 on $15^{\text {th }}$ day which were statistically insignificant. (Table 7). The vitals such as temperature, respiratory rate, pulse rate, blood pressure or SPO2 were recorded within the normal limits during the intervention period in the participants (Fig.2 and Fig.3). Temperature, Respiration rate, Pulse rate, Systolic and Diastolic Blood pressure and SPO2 were within the normal range in subgroup I on $8^{\text {th }}$ day and subgroup II on $15^{\text {th }}$ day.

Concomitant medications were taken by two participants during the study. One participant was on tab. thyroxine in the dose of $150 \mathrm{mcg}$ once daily for the past ten years for hypothyroidism and other participant was taking Tab. Telmisartan in the dose of 40 $\mathrm{mg}$ and Tab Torsemide in the dose of $5 \mathrm{mg}$ once daily for the past one year for hypertension. The rescue medications were given to six participants of the study (Table 8).

Adverse drug reaction or adverse event was not reported in any of the participant who completed the study. Only 02 participants $(5 \%)$ which do not have any existing comorbidity condition were withdrawn from the study due to Serious adverse event (SAE) reported just another day after enrolling in the study, which probably may not be due to trial drug intake. Out of the two, One participant progressed towards severe stage with chief complaint as giddiness along with tingling sensation in left arm just after two days of trial drug initiation and another participant progressed towards moderate stage with breathlessness and pain in chest just next day of initiating trial intervention. Both the participant were given oxygen therapy and subsequently referred to higher centre. 
Considering the onset of SAE in both the participants, it may be ascertained that the trial drug may be seemingly unrelated to SAE.

\section{Discussion:}

Scientific community across the globe are exploring an effective COVID 19 therapeutic intervention to contain the pandemic. In this study, the results of the administration of repurposed Ayurvedic formulation AYUSH 64 in patients with mild COVID 19 infection have been reported. The findings of the study showed the mean time for clinical recovery as 7.04 days $( \pm 2.88) .39 .2 \%$ have clinically recovered in 7 days and $53.5 \%$ recovered in 14 days. Outcome of a study on ivermectin in mild to moderate COVID 19 cases showed the total recovery time from the onset of symptoms as 10.09 \pm 3.236 days for intervention arm while $11.50 \pm 5.32$ days for control arm with no significant difference in recovery time for fever, cough, shortness of breath and resolution of symptoms between the two arms. The study reported mean recovery time in the intervention arm as $5.31 \pm 2.48$ days which did not differ significantly from the control arm where mean recovery time was $6.33 \pm 4.23$ days $^{22}$. Hydroxychloroquine administration in mild to moderate covid-19 patients admitted to hospital showed that negative conversion was not significantly higher than standard of care alone. Moreover, higher adverse events were reported in hydroxychloroquine recipients than the nonrecipients $^{23}$.

In this study, 90\% participants completed the trial and turned RT-PCR negative till 15th day, out of which $69.44 \%$ participants became RT-PCR negative on 8th day with repeat RT-PCR on 9th day (Fig 5). A study on baloxavir marboxil, favipiravir showed that the percentage of COVID 19 patients who became viral negative after 14day treatment was $70 \%, 77 \%$, respectively and $100 \%$ for control group, with the medians of time to clinical improvement as 14,14 and 15 days respectively ${ }^{24}$. A short term study of remdesivir on 53 COVID 19 patients showed that after 18 days of treatment the clinical improvement was $68 \%$ with total $13 \%$ mortality and $47 \%$ patients were discharged from hospital. The study included cases of different stages of COVID 19 infection ${ }^{25}$. A systematic review and network meta-analysis study on drug treatments for COVID 19 reported that ten randomized controlled trials on hydroxychloroquine, 
lopinavir-ritonavir, remdesivir and standard care observed no convincing evidence that these interventions increased rate of viral clearance and reduced the time to viral clearance ${ }^{26}$. A review study observed that the clinical outcomes of antiviral drugs are not consistent and found conflicting reports on oseltamivir. The study reported that eight trials on Lopinavir/ ritonavir and two randomized clinical trials on favipiravir failed in showing efficacy of the drugs in treating COVID 19 patients ${ }^{27}$.

This study showed that most of the symptoms were resolved in the participants. Cough 1(12.5\%), nasal discharge 1(12.5\%), headache 1(12.5\%) and sore throat $2(25.0 \%)$ was seen after 14 days of intervention in two participants. In a study on mild Covid-19 cases, the symptom resolution between nitazoxanide and placebo groups did not differ after 5 days of treatment ${ }^{28}$.

WHO mentions that some patients might experience certain symptoms such as post viral cough beyond the period of infectivity on which further research is required ${ }^{29}$.Urine output, bowel habit and appetite was normal in most of the participants. Disturbance in sleep was observed in a few participants. Results of a systematic review and meta-analysis study shows that SARS-CoV-2 may cause delirium in a significant proportion of patients in the acute stage and there is possibility of depression, anxiety, fatigue, post-traumatic stress disorder, and rarer neuropsychiatric syndromes in the longer term ${ }^{30}$. The trial drug may be used effectively in mild to moderate cases of COVID 19 for quick recovery. As per WHO, SARS-CoV-2 RNA has been detected in patients one to three days before the onset of the symptoms and the viral load peaks in the upper respiratory tract within first week of infection which is followed by a gradual decline over a period. The patients may still test positive for weeks for SARS-CoV2 by RT-PCR even after resolution of symptoms ${ }^{31}$. As of now, discriminating positive RTPCR test result due to COVID 19 infection recurrence or intermittent shedding of virus RNA fragments is not possible ${ }^{32}$.Given the fact, RT-PCR negative conversion of 69.44\% participants on $9^{\text {th }}$ day is quite encouraging for using AYUSH 64 as a standalone intervention in future for large scale trials on COVID 19 disease.

Though statistically insignificant but reduction in levels of Hs-CRP, IL-6, IgE, IgM, IgG was observed in the Study. IL6 expression is regarded as helpful in assessing the 
risk of progression to severe condition, and higher CRP is an indicative of poor prognosis and severe disease ${ }^{33}$. A meta-analysis and review studies have found that decreased S. Albumin, elevated CRP, LDH Lymphopenia and high ESR ${ }^{34}$ along with increased D-dimer and low hemoglobin were most common laboratory features reported in COVID $19^{35}$. The observations of reduction in levels of Hs-CRP, IL-6, IgE, in the trial have shown that AYUSH 64 as standalone intervention has effectively checked disease progression in asymptomatic and mild COVID 19 cases.

No Adverse event / Adverse drug reaction (AE/ADR) has been reported during the study period in any of the participants who completed this study. A study has reported $66 \%$ of adverse events due to Remdesivir treatment in comparison to $64 \%$ in placebo treatment ${ }^{36}$. Another review study reported most common adverse events of remdesivir as gastrointestinal side effects (nausea, constipation, diarrhoea) and graded elevation in alanine transaminase and aspartate transaminase along with hepatic toxicity which lead to discontinuation of drug in $10 \%$ cases in a randomized control trial. The study reported adverse events of Lopinavir/ ritonavir as increase in alanine transaminase, gastrointestinal side effects such as diarrhoea, loss of appetite, nausea and vomiting and for favipiravir as diarrhoea, liver toxicity, hyperuricemia in some patients. Further, some studies on Lopinavir/ ritonavir were discontinued due to severe gastrointestinal side effects, hypokalemia, and skin eruptions ${ }^{37}$. Adverse events were more commonly observed in the the hydroxychloroquine group (50.00\%) and the chloroquine group $(44.44 \%)$ compared to the control group $(16.67 \%)^{38}$. A Systematic Review and Metaanalysis showed that there was a higher risk of ECG abnormalities/arrhythmia with hydroxychloroquine / chloroquine ${ }^{39}$.

Ayurvedic Clinical profile of COVID 19 based on a study is classified as agantuja jvara having vatakapha pradhana sannipata presentation with a consideration of dominance of Pitta at certain stages and some patients of COVID $19^{40}$. Another study has proposed the Ayurveda protocol for treatment of COVID 19 ${ }^{41}$. The constituents of AYUSH 64 have been reported to have antipyretic, hepatoprotective, antiinflammatory, antioxidant, antiviral ${ }^{424344454647484950}$ and Immunostimulatory and immunomodulatory properties ${ }^{5152535455565758}$ Ayurveda aims at digestion of Ama (toxic 
by-products of partially digested food) for the treatment of Jvara for which langhana (fasting) along with Ayurveda single and polyhedral formulations having tikta rasa (bitter taste), ushna virya (hot potency), katu (pungent) vipaka and amapachaka (toxins alleviating/ anti-inflammatory) properties are described ${ }^{59}$. The constituents of the trial drug are tiktarasatmak, which pacifies the vitiated Kapha and neutralize the Amavisha through its Deepaniya (stomachic), Pachaniya (digestant), and shodhan (purification) properties $^{60}$ and hence Jvaraghana (relieves fever), Sannipatajwarahara (relieves recurrent fevers), Krimihara (wormicidal), Jantuhara (anthelminthic), and Shothahara (anti-inflammatory). Ayurveda drugs strengthen Agni (digestive functions along with metabolic functions), Bala (innate strength) and restores balance among the Doshas and hence restores the overall functional integrity in order to overcome infection and recover from disease making this as potent therapy against COVID-19. About $81 \%$ COVID 19 cases are mild to moderate with mild symptoms up to mild pneumonia ${ }^{61}$. This study reflects the reasonable and plausible aspects that Ayurveda can provide management care for the patients diagnosed with asymptomatic, mild to moderate COVID 19.

\section{Study limitations:}

This is a pilot standalone intervention study with small sample size, non-blinded design, no comparator arm and conducted only in mild to moderate COVID 19 cases, which limits the data being generated on efficacy and safety profile of the trial drug. Preliminary clinical data is insufficient to elicit favourable risk/benefit profile for treatment of COVID-19. The effect of the trial drug on few more inflammatory and other laboratory parameters could have also been evaluated in the study which could not be realized due to logistical constraints.

\section{Conclusion:}

AYUSH 64 may be effectively used in asymptomatic, mild to moderate cases of COVID 19. The study provides the evidence of early clinical recovery with significant improvement in COVID-19 symptoms and the levels of inflammatory markers in asymptomatic, mild to moderate COVID 19 cases. AYUSH 64 has been well tolerated, no significant SAE/ADR was reported and no progression of the disease in 
asymptomatic and mild COVID-19 cases to severe cases was seen. Repurposing the drug in COVID 19 could potentially offer a promising solution and rapid strategy in alleviating the infection and establishing an anti COVID-19 therapy in the country. AYUSH 64 has much broader spectrum of properties including antiviral, antipyretic, immune-stimulant and immunomodulatory activities, which could open new perspectives for effective and safe treatment in asymptomatic, mild to moderate cases of COVID-19.

However, statistical robustness of the results is limited to small sample size for which large-scale double blind Randomized Controlled Trial with better end-points may be designed to elucidate conclusive evidence on efficacy and safety profile of AYUSH 64 in COVID 19 treatment.

\section{Ethics Approval and Trial registration}

The study has been approved by institutional ethics committee and registered prospectively at Clinical Trial Registry India with registration no. CTRI/2020/05/025338

\section{Conflict of Interest-Nil}

\section{Acknowledgments}

The authors are thankful to CCRAS, Ministry of AYUSH, Government. of India for grants for this study under CCRAS Research policy and Dr. Mohmmad Idris, Principal/MS, A and U Tibbia College and Hospital, Dr. Jagnnath Verma, Dr. Ankur Tanwar, Dr. Barkha for their support.

Source of support: Central Council for Research in Ayurvedic Sciences,New Delhi Ministry of Ayush, Government of India 
Table 1: Composition of each $500 \mathrm{mg}$ tablet of AYUSH 64 


\begin{tabular}{|c|c|c|c|c|c|c|}
\hline $\begin{array}{l}\text { Sr. } \\
\text { No }\end{array}$ & Ingredients & $\begin{array}{l}\text { Scientific } \\
\text { name }\end{array}$ & $\begin{array}{l}\text { Part } \\
\text { used }\end{array}$ & Ratio & $\begin{array}{l}\text { Actions as per } \\
\text { Ayurveda }\end{array}$ & Pharmacological actions \\
\hline 1 & Saptaparna & $\begin{array}{l}\text { Alstonia } \\
\text { scholaris }\end{array}$ & $\begin{array}{l}\text { Root } \\
\text { Bark } \\
\text { Aqueous } \\
\text { Extract }\end{array}$ & $\begin{array}{l}100 \\
m g .\end{array}$ & $\begin{array}{l}\text { Jvara, Swasa* } \\
\text { (API Part I, Vol- } \\
\text { I, pg-169) }\end{array}$ & $\begin{array}{l}\text { Anti-inflammatory, Analgesic, } \\
\text { Antioxidant, } \\
\text { Immunomodulatory, } \\
\text { Antimicrobial, } \\
\text { Hepatoprotective, } \\
\text { Antimalarial, Antifilarial } \\
\text { (*Reviews on Indian Medicinal } \\
\text { Plants, Vol-2, ICMR; Jian-Hua } \\
\text { Shang et al. 2010; Arulmozhi.S } \\
\text { et al. 2007) }\end{array}$ \\
\hline 2 & Katuki & $\begin{array}{l}\text { Picrorhiza } \\
\text { kurroa } \\
\text { Royle ex. } \\
\text { Benth }\end{array}$ & $\begin{array}{l}\text { Root } \\
\text { Aqueous } \\
\text { Extract }\end{array}$ & $\begin{array}{l}100 \\
m g\end{array}$ & $\begin{array}{l}\text { Jvara, } \\
\text { Vishamjvara, } \\
\text { Swasa, Kaasa, } \\
\text { Daaha, } \\
\text { Krimiroga, } \\
\text { Arochaka\# (API } \\
\text { Part I, Vol II,pg- } \\
\text { 93) }\end{array}$ & $\begin{array}{l}\text { Immunostimulant, } \\
\text { Immunomodulatory, Anti- } \\
\text { inflammatory, } \\
\text { Antipyretic,Antioxidant, } \\
\text { Antiviral, Antihistaminic, } \\
\text { Antimicrobial, } \\
\text { Hepatoprotective, } \\
\text { Renoprotective effects\# } \\
\text { (Reviews on Indian Medicinal } \\
\text { Plants, Vol-20, ICMR; Umme } \\
\text { Salma et al. 2017) }\end{array}$ \\
\hline 3 & Kiratatikta & $\begin{array}{l}\text { Swertia } \\
\text { chirata } \\
\text { Pexbex. } \\
\text { Karst }\end{array}$ & $\begin{array}{l}\text { Whole- } \\
\text { plant } \\
\text { Aqueous } \\
\text { Extract }\end{array}$ & $\begin{array}{l}100 \\
m g .\end{array}$ & $\begin{array}{l}\text { Sannipata } \\
\text { jvara, } \\
\text { Swasa,Kaasa, } \\
\text { Daaha, Shotha, } \\
\text { Trishna, } \\
\text { Krimiroga, } \\
\text { Kandu (API } \\
\text { Part I, Vol-I, pg- } \\
\text { 127) }\end{array}$ & $\begin{array}{l}\text { Antipyretic,Anti-inflammation, } \\
\text { Anti-oxidant, Anti-viral, } \\
\text { Hepatoprotective, Antibacterial, } \\
\text { Antifungal activity (Vijay Kumar } \\
\text { et al 2016, Sushil Bhargava et } \\
\text { al.2009) }\end{array}$ \\
\hline
\end{tabular}




\begin{tabular}{|c|c|c|c|c|c|c|}
\hline 4 & Kuberaksha & $\begin{array}{l}\text { Caesalpinia } \\
\text { crista } L \text {. }\end{array}$ & $\begin{array}{l}\text { Seed } \\
\text { Powder }\end{array}$ & $\begin{array}{l}200 \\
m g\end{array}$ & $\begin{array}{l}\text { Vishamajvara, } \\
\text { Kasa, Shotha, } \\
\text { Swasa, } \\
\text { Agnimandya, } \\
\text { Pravahika, } \\
\text { Yakritpliharoga, } \\
\text { Krimiroga } \\
\text { (API Part I, Vol- } \\
\text { V, pg-15) }\end{array}$ & $\begin{array}{l}\text { Antiviral, Anti-inflammatory, } \\
\text { Anti diarrhoeal, } \\
\text { Antioxidant,Hepatoprotective, } \\
\text { Antimicrobial activities, } \\
\text { Immunomodulatory } \\
\text { (Reviews on Indian Medicinal } \\
\text { Plants, Vol-5, ICMR) }\end{array}$ \\
\hline
\end{tabular}




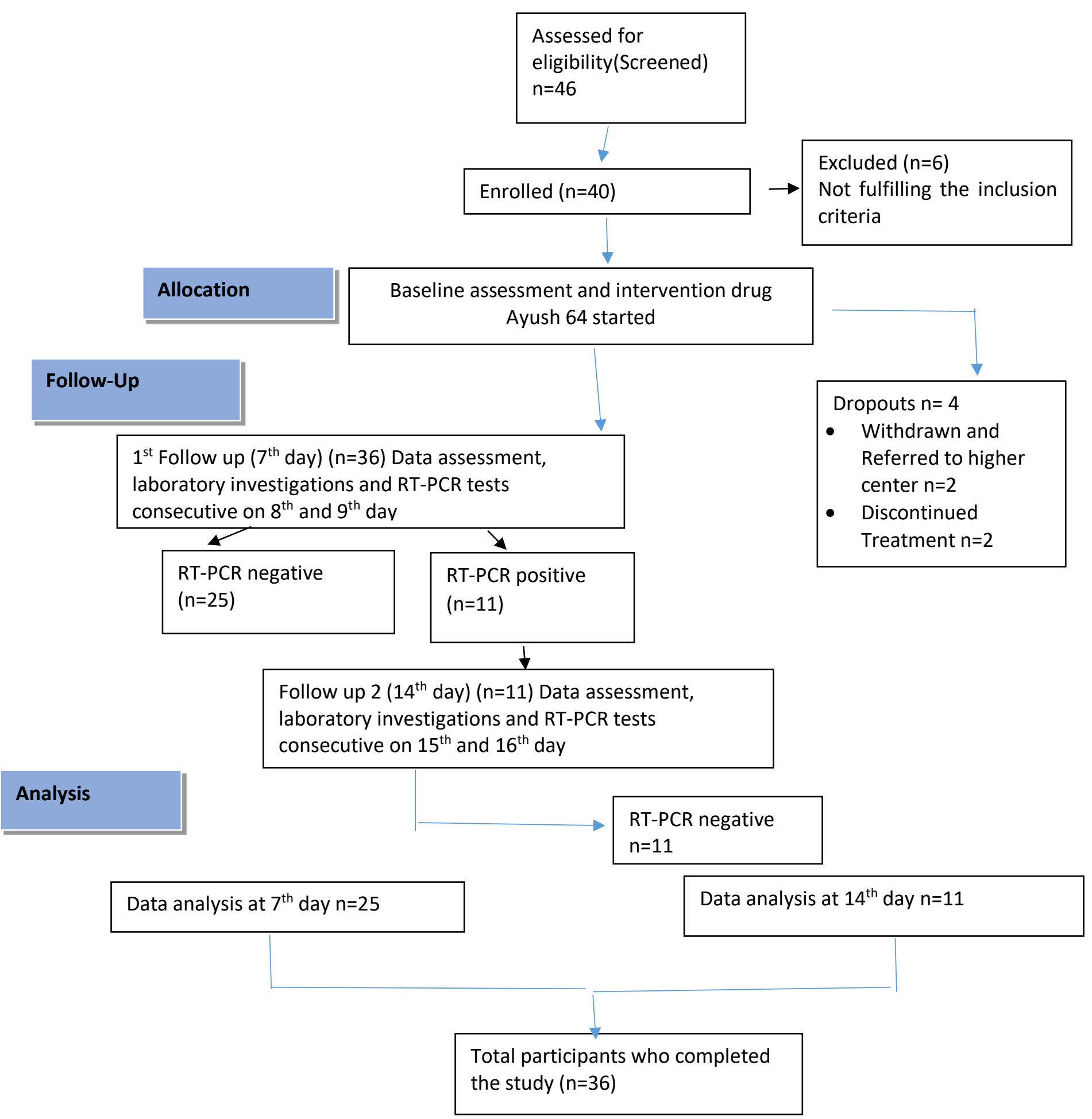


Table 2: Baseline Characteristics:

\begin{tabular}{|c|c|}
\hline Characteristics & \\
\hline Age: Mean (SD) & $28.80(8.94)$ \\
\hline \multicolumn{2}{|l|}{ Gender } \\
\hline Male & $28(78.4 \%)$ \\
\hline Female & $08(21.6 \%)$ \\
\hline \multicolumn{2}{|l|}{ Marital Status } \\
\hline Married & $14(40.5 \%)$ \\
\hline Unmarried & $22(59.5 \%)$ \\
\hline \multicolumn{2}{|l|}{ Educational status } \\
\hline Illiterate & $06(16.7 \%)$ \\
\hline Upto 10 ${ }^{\text {th }}$ & $11(30.6 \%)$ \\
\hline Upto $12^{\text {th }}$ & $06(16.7 \%)$ \\
\hline Graduate & $12(33.3 \%)$ \\
\hline Post graduate & $01(2.8 \%)$ \\
\hline \multicolumn{2}{|l|}{ Occupation } \\
\hline Desk work & $1(5.4 \%)$ \\
\hline Field work with physical labour & $9(24.3 \%)$ \\
\hline Field work & $16(43.2 \%)$ \\
\hline House wife & $2(5.4 \%)$ \\
\hline Student & $8(21.6 \%)$ \\
\hline \multicolumn{2}{|l|}{ Habitat } \\
\hline Urban & $22(62.2 \%)$ \\
\hline Semi-urban & $03(8.1 \%)$ \\
\hline Rural & $11(29.7 \%)$ \\
\hline \multicolumn{2}{|l|}{ Economic status } \\
\hline Above poverty line & $20(56.8 \%)$ \\
\hline Below poverty line & $16(43.2 \%)$ \\
\hline \multicolumn{2}{|l|}{ Co-morbidities } \\
\hline COPD & 0 \\
\hline Chronic Renal Disease & 0 \\
\hline Bronchitis & 0 \\
\hline Diabetes & 0 \\
\hline Heart Disease & 0 \\
\hline Hypertension & $2(5.55 \%)$ \\
\hline Asthma & 0 \\
\hline \multicolumn{2}{|l|}{ Risk Factor } \\
\hline $\begin{array}{l}\text { Travel / residence in COVID hotspots/ } \\
\text { endemic areas }\end{array}$ & $13(36.1 \%)$ \\
\hline Workplace exposure to COVID 19 cases & $18(50.0 \%)$ \\
\hline $\begin{array}{l}\text { Direct/indirect Contact with COVID } 19 \\
\text { Cases (Except workplace exposure) }\end{array}$ & $16(44.5 \%)$ \\
\hline
\end{tabular}


Table 3: Observations for AYUSH 64 on clinical Symptoms and Signs (Present) at Baseline, $7^{\text {th }}$ and $14^{\text {th }}$ day

\begin{tabular}{|c|c|c|c|c|c|}
\hline \multirow[t]{2}{*}{$\begin{array}{l}\text { Clinical Sign \& } \\
\text { Symptoms present }\end{array}$} & \multicolumn{2}{|l|}{$\begin{array}{l}\text { Subgroup I } \\
(\mathbf{n}=\mathbf{2 0})\end{array}$} & \multicolumn{3}{|c|}{$\begin{array}{l}\text { Subgroup II } \\
(n=8)\end{array}$} \\
\hline & Baseline & $7^{\text {th }}$ day & Baseline & $7^{\text {th }}$ day & 14th day \\
\hline Fever at evaluation & $5(25.0 \%)$ & 0 & $1(12.5 \%)$ & 0 & 0 \\
\hline Cough & $13(65.0 \%)$ & $7(35.0 \%)$ & $4(50.0 \%)$ & $1(12.5 \%)$ & $1(12.5 \%)$ \\
\hline Breathlessness & $8(40.0 \%)$ & 0 & 0 & $1(12.5 \%)$ & 0 \\
\hline Sore Throat & $9(45.0 \%)$ & $3(15.0 \%)$ & $3(37.5 \%)$ & $3(37.5 \%)$ & $2(25.0 \%)$ \\
\hline Sputum & $2(10.0 \%)$ & 0 & & & \\
\hline Nausea & $1(5.0 \%)$ & 0 & $3(37.5 \%)$ & $1(12.5 \%)$ & 0 \\
\hline Body ache & $4(20.0 \%)$ & $2(10.0 \%)$ & $3(37.5 \%)$ & $1(12.5 \%)$ & 0 \\
\hline Abdominal Pain & $2(10.0 \%)$ & 0 & $1(12.5 \%)$ & 0 & 0 \\
\hline Headache & $5(25.0 \%)$ & $4(20.0 \%)$ & $3(37.5 \%)$ & $1(12.5 \%)$ & $1(12.5 \%)$ \\
\hline Nasal discharge & $5(25.0 \%)$ & $2(10.0 \%)$ & $1(12.5 \%)$ & $1(12.5 \%)$ & $1(12.5 \%)$ \\
\hline Chest pain & $4(20.0 \%)$ & 0 & $2(25.0 \%)$ & 0 & 0 \\
\hline Anorexia & $2(10.0 \%)$ & $1(5.0 \%)$ & 0 & $1(12.5 \%)$ & 0 \\
\hline Vomiting & $1(5.0 \%)$ & $1(5.0 \%)$ & $1(12.5 \%)$ & $1(12.5 \%)$ & 0 \\
\hline \multicolumn{6}{|c|}{$\begin{array}{l}\text { Values have been represented as n (\%) } \\
\text { Subgroup I - Participants who completed the trial on } 8^{\text {th }} \text { Day } \\
\text { Subgroup II - Participants who completed the trial on } 15^{\text {th }} \text { Day }\end{array}$} \\
\hline
\end{tabular}


Table:4Ayurvedic Parameters of Jwara

\begin{tabular}{|c|c|c|c|c|c|}
\hline \multirow[t]{2}{*}{$\begin{array}{l}\text { Ayurvedic Parameters of } \\
\text { Jwara }\end{array}$} & \multicolumn{2}{|l|}{$\begin{array}{l}\text { Subgroup I } \\
\mathrm{n}=25\end{array}$} & \multicolumn{3}{|c|}{$\begin{array}{c}\text { Subgroup II } \\
n=11\end{array}$} \\
\hline & Baseline & $7^{\text {th }}$ day & Baseline & $7^{\text {th }}$ day & 14th day \\
\hline Laziness & $11(44.0 \%)$ & $3(12.0 \%)$ & $3(27.3 \%)$ & $4(36.4 \%)$ & $3(27.3 \%)$ \\
\hline Watering of eyes & $4(16.0 \%)$ & 0 & $1(9.1 \%)$ & 0 & 0 \\
\hline Burning sensation in eyes & $1(4.0 \%)$ & 0 & $1(9.1 \%)$ & 0 & 0 \\
\hline Excessive yawning & $3(12.0 \%)$ & $2(8.0 \%)$ & $1(9.1 \%)$ & $1(9.1 \%)$ & $1(9.1 \%)$ \\
\hline Heaviness in body & $4(16.0 \%)$ & $3(12.0 \%)$ & $2(18.2 \%)$ & $1(9.1 \%)$ & $1(9.1 \%)$ \\
\hline $\begin{array}{l}\text { Exhaustion without } \\
\text { exertion }\end{array}$ & $7(28.0 \%)$ & 0 & $3(27.3 \%)$ & $1(9.1 \%)$ & $1(9.1 \%)$ \\
\hline $\begin{array}{l}\text { Exhaustion with minimal } \\
\text { exertion }\end{array}$ & $6(24.0 \%)$ & $2(8.0 \%)$ & $2(18.2 \%)$ & 0 & $1(9.1 \%)$ \\
\hline Fatigue & $11(44.0 \%)$ & $8(32.0 \%)$ & $6(54.5 \%)$ & $7(63.6 \%)$ & $1(9.1 \%)$ \\
\hline $\begin{array}{l}\text { Frequently changing } \\
\text { affection and aversions for } \\
\text { sound, heat, sunlight, wind, } \\
\text { water etc }\end{array}$ & $3(12.0 \%)$ & $1(4.0 \%)$ & 0 & 0 & 0 \\
\hline No desire for food & $3(12.0 \%)$ & $1(4.0 \%)$ & $2(18.2 \%)$ & $3(27.3 \%)$ & $1(9.1 \%)$ \\
\hline Indigestion & $1(4.0 \%)$ & 0 & $3(27.3 \%)$ & $3(27.3 \%)$ & $1(9.1 \%)$ \\
\hline Tastelessness & $9(36.0 \%)$ & $1(4.0 \%)$ & $2(18.2 \%)$ & $3(27.3 \%)$ & $1(9.1 \%)$ \\
\hline Depletion in strength & $6(24.0 \%)$ & 0 & $1(9.1 \%)$ & 0 & 0 \\
\hline Feeling fatigued & $6(24.0 \%)$ & $1(4.0 \%)$ & $2(18.2 \%)$ & 0 & 0 \\
\hline Depletion of skin luster & $2(8.0 \%)$ & 0 & 0 & $1(9.1 \%)$ & 0 \\
\hline Slight change in behavior & $3(12.0 \%)$ & 0 & $1(9.1 \%)$ & 0 & 0 \\
\hline Agitated eyes & $2(8.0 \%)$ & 0 & $1(9.1 \%)$ & 0 & 0 \\
\hline Excessive sleep & $4(16.0 \%)$ & 0 & $1(9.1 \%)$ & $1(9.1 \%)$ & $2(18.2 \%)$ \\
\hline Restlessness & $5(20.0 \%)$ & $(4.0 \%)$ & $3(27.3 \%)$ & 0 & 0 \\
\hline $\begin{array}{l}\text { Bending of body/feeling as } \\
\text { if muscles and body are } \\
\text { contracting }\end{array}$ & $1(4.0 \%)$ & 0 & 0 & 0 & 0 \\
\hline Giddiness/ vertigo & $2(8.0 \%)$ & $1(4.0 \%)$ & 0 & 0 & 0 \\
\hline Insomnia & $3(12.0 \%)$ & $1(4.0 \%)$ & $1(9.1 \%)$ & 0 & $1(9.1 \%)$ \\
\hline Weakness & $13(52.0 \%)$ & $4(16.0 \%)$ & $6(54.5 \%)$ & $7(63.6 \%)$ & $1(9.1 \%)$ \\
\hline Generalized body ache & $8(32.0 \%)$ & $4(16.0 \%)$ & $6(54.5 \%)$ & $5(45.5 \%)$ & $1(9.1 \%)$ \\
\hline $\begin{array}{l}\text { Slowness in activities], } \\
\text { taking comparatively longer } \\
\text { duration for a routine work }\end{array}$ & $1(4.0 \%)$ & 0 & 0 & 0 & 0 \\
\hline $\begin{array}{l}\text { Inability to do regular } \\
\text { functions }\end{array}$ & $1(4.0 \%)$ & 0 & $1(9.1 \%)$ & 0 & 0 \\
\hline $\begin{array}{l}\text { Difficulty in } \\
\text { deglutition/ingestion of food }\end{array}$ & $1(4.0 \%)$ & 0 & 0 & 0 & 0 \\
\hline Aversion for sweets & $1(4.0 \%)$ & 0 & 0 & 0 & 0 \\
\hline $\begin{array}{l}\text { Sudden affection for sour, } \\
\text { salty and pungent tastes }\end{array}$ & $4(16.0 \%)$ & 0 & 0 & 0 & 0 \\
\hline $\begin{array}{l}\text { Values have been represente } \\
\text { Subgroup I- Participants wh } \\
\text { Subgroup II- Participants wl }\end{array}$ & as Count( & centage) & Day & & \\
\hline
\end{tabular}


Table 5: Effect of AYUSH 64 on outcome measures

\begin{tabular}{|c|c|c|c|}
\hline \multirow{3}{*}{$\begin{array}{l}\text { Primary } \\
\text { outcome } \\
\text { measures }\end{array}$} & \multicolumn{2}{|c|}{$\begin{array}{l}\text { Mean time (days) for clinical recovery as per clinical } \\
\text { recovery }\end{array}$} & \multirow{2}{*}{$\begin{array}{l}7.04 \pm 2.88 \\
\text { days }\end{array}$} \\
\hline & \multirow{2}{*}{$\begin{array}{l}\text { Number of patients showing } \\
\text { 'clinical recovery' }(\mathrm{n}=28)\end{array}$} & $7^{\text {th }}$ Day & \\
\hline & & $14^{\text {th }}$ Day & $15(53.5 \%)$ \\
\hline \multirow{5}{*}{$\begin{array}{l}\text { Secondary } \\
\text { outcome } \\
\text { measures }\end{array}$} & \multirow{2}{*}{$\begin{array}{l}\text { Percentage of patients with } \\
\text { negative SARS-CoV- } 2 \text { on } \\
\text { nasal or throat swab in a } 2 \text { day } \\
\text { continuous real time RT-PCR } \\
\text { test }\end{array}$} & $9^{\text {th }}$ Day & $25(69.44)$ \\
\hline & & $16^{\text {th }}$ Day & $11(30.55)$ \\
\hline & \multicolumn{2}{|c|}{ No of cases reporting any ADR/AE } & $0(0 \%)$ \\
\hline & \multicolumn{2}{|c|}{$\begin{array}{l}\text { Number of participants referred with onset of } \\
\text { complications }\end{array}$} & $2(5 \%)$ \\
\hline & \multicolumn{2}{|c|}{$\begin{array}{l}\text { Number of participants that required invasive or non- } \\
\text { invasive oxygen therapy during the intervention. }\end{array}$} & $0(0 \%)$ \\
\hline \multicolumn{4}{|c|}{ Values represented as n (\%) } \\
\hline
\end{tabular}


Table 6:Effect of AYUSH 64 on Laboratory parameters in two Subgroups

\begin{tabular}{|c|c|c|c|c|c|c|c|}
\hline & \multicolumn{3}{|c|}{ Subgroup I $(n=25)$} & \multicolumn{4}{|c|}{ Subgroup II $(n=11)$} \\
\hline $\begin{array}{l}\text { Laboratory } \\
\text { Parameters } \\
\text { (Reference } \\
\text { Range) }\end{array}$ & Baseline & $8^{\text {th }}$ Day & $\begin{array}{l}\text { p- } \\
\text { value\# }\end{array}$ & Baseline & $8^{\text {th }}$ Day & $15^{\text {th }}$ Day & $\begin{array}{l}\text { p- } \\
\text { value } \\
\$\end{array}$ \\
\hline $\begin{array}{l}\text { Hemoglobin } \\
\text { (g/dl) }\end{array}$ & $13.80(2.19)$ & $13.90(2.12)$ & 0.449 & $14.32(1.87)$ & $14.55(1.66)$ & $14.73(1.54)$ & 0.158 \\
\hline T.L.C $\left(10^{\wedge} 3 / \mu L\right)$ & $7.05(1.78)$ & $7.25(1.82)$ & 0.554 & $5.64(1.51)$ & $6.61(1.67)$ & $7.59(2.25)$ & 0.001 \\
\hline $\mathbf{N}(\%)$ & $55.72(7.92)$ & $55.88(9.85)$ & 0.928 & $47.36(7.85)$ & $48.55(6.27)$ & $53.27(8.29)$ & 0.071 \\
\hline E (\%) & $3.48(1.33)$ & $3.32(1.60)$ & 0.590 & $3.82(2.78)$ & $4.91(3.36)$ & $5.73(3.35)$ & 0.153 \\
\hline B (\%) & $0.12(0.33)$ & $0.16(0.37)$ & 0.664 & $0.09(0.30)$ & $0.36(0.50)$ & $0.00(0.00)$ & 0.067 \\
\hline $\mathbf{L}(\%)$ & $34.44(7.67)$ & $34.36(7.98)$ & 0.955 & $42.64(10.04)$ & $39.91(6.55)$ & $35.55(6.68)$ & 0.064 \\
\hline M (\%) & $5.84(2.09)$ & $6.28(2.91)$ & 0.538 & $6.09(1.51)$ & $6.27(2.05)$ & $5.45(2.21)$ & 0.475 \\
\hline $\begin{array}{l}\text { Absolute } \\
\text { lymphocyte } \\
\text { (/cu.mm)Baseline }\end{array}$ & $2360.96(592.51)$ & $2405.24(658.67)$ & 0.726 & $2381.73(788.22)$ & $\begin{array}{l}\text { 2605.36(616.6 } \\
7)\end{array}$ & $2553.82(533.83)$ & 0.581 \\
\hline $\begin{array}{l}\text { E.S.R. } \\
(\mathbf{m m} / \text { hour })\end{array}$ & $12(8-28)$ & $16(8-22)$ & 0.871 & $10(5-12)$ & $8(6.5-8)$ & $10(10-19.5)$ & 0.378 \\
\hline $\begin{array}{l}\text { Blood Sugar } \\
\text { Fasting }(\mathrm{mg} / \mathrm{dL})\end{array}$ & $86.52(8.59)$ & $91.04(14.58)$ & 0.119 & $85.45(8.53)$ & $82.18(5.29)$ & $86.55(9.19)$ & 0.256 \\
\hline HbA1c $(\%)$ & $5.124(0.35)$ & $5.208(0.47)$ & 0.110 & $4.97(0.49)$ & $5.06(0.64)$ & $5.00(0.42)$ & 0.726 \\
\hline Hs-CRP(mg/L) & $4.68(9.77)$ & $2.632(3.72)$ & 0.348 & $2.25(3.95)$ & $3.58(8.64)$ & $1.03(1.52)$ & 0.586 \\
\hline IL-6(pg/mL) & $14.7(4-111.3)$ & $\begin{array}{l}26.7 \quad(12.8- \\
120.75)\end{array}$ & 0.710 & $\begin{array}{l}33.6 \quad(11.15- \\
151.47)\end{array}$ & $\begin{array}{lll}6.9 \quad(0.8 & - \\
229.5) & \end{array}$ & $\begin{array}{l}0.1 \\
26.82)\end{array}(0.06-$ & 0.052 \\
\hline Ig E(IU/mL) & $285(51.8-532.1)$ & $332(129-1000)$ & 0.158 & $392(12.9-3000)$ & $\begin{array}{l}1392(15.53- \\
3000)\end{array}$ & $\begin{array}{lll}206.9 & (4.8 & - \\
3000) & & \end{array}$ & 0.347 \\
\hline Ig-G(mg/dL) & $1494.62(319.16)$ & $1447.99(335.97)$ & 0.167 & $1615.04(338.76)$ & $\begin{array}{l}1631.09(502.7 \\
5)\end{array}$ & $1635.73(386.50)$ & 0.938 \\
\hline Ig-M(mg/dL) & $126.128(55.59)$ & $123.152(63.30)$ & 0.717 & $99.715(58.97)$ & $97.91(55.17)$ & $98.11(56.99)$ & 0.929 \\
\hline $\begin{array}{l}\text { Sub group I: Parti } \\
\text { Sub group II: Par } \\
\text { Values have been } \\
\text { \#Compared using } \\
\text { \$Compared using } \\
\text { p-value of }<0.05 \mathrm{~h}\end{array}$ & $\begin{array}{l}\text { ipants who compl } \\
\text { cipants who comp } \\
\text { epresented as Mea } \\
\text { aired sample } t \text { - } t \\
\text { Repeated Measure } \\
\text { s been considered }\end{array}$ & $\begin{array}{l}\text { ted the study at } 81 \\
\text { eted the study at } 1 \\
\text { (SD) / Median (I } \\
\text { st / Wilcoxon sign } \\
\text { ANOVA / Friedm } \\
\text { as significant }\end{array}$ & $\begin{array}{l}\text { ( day } \\
\text { 5th day } \\
\text { QR) } \\
\text { rank test } \\
\text { n test }\end{array}$ & & & & \\
\hline
\end{tabular}


Table 7: Effect of AYUSH 64 on Safety Parameters Liver and Kidney Function in two subgroups

\begin{tabular}{|c|c|c|c|c|c|c|c|}
\hline \multirow{2}{*}{$\begin{array}{l}\text { Safety Parameters } \\
\text { (Reference Range) }\end{array}$} & \multicolumn{3}{|c|}{ Subgroup I $(n=25)$} & \multicolumn{4}{|c|}{ Subgroup II $(\mathrm{n}=11)$} \\
\hline & Baseline & $8^{\text {th }}$ Day & $\begin{array}{l}\text { p- } \\
\text { value\# }\end{array}$ & Baseline & $8^{\text {th }}$ Day & $15^{\text {th }}$ Day & $\begin{array}{l}\text { p- } \\
\text { value } \\
\$\end{array}$ \\
\hline $\begin{array}{l}\text { Serum } \\
\text { Creatinine }(\mathrm{mg} / \mathrm{dL})\end{array}$ & $0.87(0.158)$ & $0.78(0.207)$ & 0.054 & $0.89(0.14)$ & $0.88(0.12)$ & $0.78(0.21)$ & 0.261 \\
\hline $\begin{array}{l}\text { S.G.P.T } \\
\text { (A.L.T.)(U/L) }\end{array}$ & $40.32(19.31)$ & $34.88(17.61)$ & 0.184 & $37.73(17.97)$ & $75.64(139.42)$ & $43.36(41.80)$ & 0.393 \\
\hline $\begin{array}{l}\text { Total } \\
\operatorname{protein}(g m / d L)\end{array}$ & $7.95(0.83)$ & $7.37(0.75)$ & 0.015 & $7.67(0.64)$ & $7.33(0.43)$ & $7.89(0.88)$ & 0.197 \\
\hline S.Albumin(gm/dL) & $4.53(0.42)$ & $4.46(0.41)$ & 0.460 & $4.35(0.36)$ & $4.53(0.14)$ & $4.60(0.42)$ & 0.174 \\
\hline $\begin{array}{l}\text { Unconjugated } \\
\text { bilirubin(mg/dL) }\end{array}$ & $0.61(0.40)$ & $0.58(0.34)$ & 0.668 & $0.66(0.65)$ & $0.55(0.33)$ & $0.62(0.41)$ & 0.632 \\
\hline $\begin{array}{l}\text { Serum Alkaline } \\
\text { Phosphatase(U/L) }\end{array}$ & $127.24(52.28)$ & $111.72(41.87)$ & 0.128 & $112.0(32.57)$ & $107.09(27.12)$ & $120.45(38.18)$ & 0.450 \\
\hline \multicolumn{8}{|c|}{$\begin{array}{l}\text { Sub group I: Participants who completed the study at 8th day } \\
\text { Sub group II: Participants who completed the study at 15th day } \\
\text { Values have been represented as Mean } \pm \text { SD \#Compared using paired sample } t-\text { test / Wilcoxon sign rank test } \\
\text { \$Compared using Repeated Measure ANOVA / Friedman test } \\
\text { p-value of }<0.05 \text { has been considered as significant }\end{array}$} \\
\hline
\end{tabular}


Table 8: Details of Rescue Medicine

\begin{tabular}{|c|c|c|c|c|c|c|c|}
\hline $\begin{array}{l}\text { Assessm } \\
\text { ent Visit }\end{array}$ & $\begin{array}{l}\text { Total } \\
\text { Praticipa } \\
\text { nts }\end{array}$ & $\begin{array}{l}\text { Partcip } \\
\text { ant } \\
\text { Enrol } \\
\text { No. }\end{array}$ & $\begin{array}{l}\text { Rescue } \\
\text { medicines }\end{array}$ & Dose & $\begin{array}{l}\text { Duratio } \\
n \text { of } \\
\text { intake }\end{array}$ & Cause & $\begin{array}{l}\text { Prescription/ } \\
\text { Self } \\
\text { Medication }\end{array}$ \\
\hline \multirow[t]{6}{*}{$7^{\text {th }}$ day } & \multirow[t]{6}{*}{06} & A 10 & $\begin{array}{l}\text { Diclofenac } \\
\text { Rantac }\end{array}$ & $\begin{array}{l}75 \mathrm{mg} \\
150 \\
\mathrm{mg}\end{array}$ & 1 Day & Headache & Prescription \\
\hline & & A 25 & $\begin{array}{l}\text { T.Azithrom } \\
\text { ycin } \\
\text { Syp. } \\
\text { Diphenyla } \\
\text { mine }\end{array}$ & $\begin{array}{l}500 \\
\mathrm{mg} \\
\text { OD } \\
1 \mathrm{TSF} \\
\mathrm{BD}\end{array}$ & 1 Day & $\begin{array}{l}\text { Throat } \\
\text { Pain } \\
\text { Cough } \\
\text { and Cold }\end{array}$ & $\begin{array}{l}\text { Self } \\
\text { medication } \\
\text { from the } \\
\text { medicine } \\
\text { given to the } \\
\text { participant } \\
\text { by the } \\
\text { referred } \\
\text { center }\end{array}$ \\
\hline & & A 26 & $\begin{array}{l}\text { PCM } \\
\text { Amlodipine } \\
\text { Shitopladi } \\
\text { Vasavleh }\end{array}$ & $\begin{array}{l}500 \mathrm{~m} \\
\mathrm{~g} / 2 \\
\mathrm{gm} \\
5 \mathrm{mg} \\
\text { OD } \\
1 \mathrm{BD} \\
1 \mathrm{TSF}\end{array}$ & $\begin{array}{l}3 \text { days } \\
1 \text { day } \\
\text { Contin } \\
\text { ued } \\
1 \text { Day }\end{array}$ & $\begin{array}{l}\text { Fever/ } \\
\text { /Cough } \\
\text { And Cold } \\
\text { Hypertens } \\
\text { ion }\end{array}$ & Prescription \\
\hline & & A28 & $\begin{array}{l}\text { Sitopaladi } \\
\text { ch. } \\
\text { Lavangadi } \\
\text { vati }\end{array}$ & $\begin{array}{l}5 \mathrm{gm} \\
\mathrm{Tab} \\
2 \mathrm{BD}\end{array}$ & $\begin{array}{l}3 \text { days } \\
3 \text { days }\end{array}$ & $\begin{array}{l}\text { Productiv } \\
\text { e Cough } \\
\text { \& Cold, } \\
\text { Sneezing }\end{array}$ & Prescription \\
\hline & & A30 & $\begin{array}{l}\text { PCM/ } \\
\text { Shitopladi } \\
\text { Ch. }\end{array}$ & $\begin{array}{l}\begin{array}{l}500 \mathrm{~m} \\
\mathrm{~g} \mathrm{SOS}\end{array} \\
2 \mathrm{gm} \\
\text { TDS }\end{array}$ & $\begin{array}{l}2 \text { days } \\
3 \text { days }\end{array}$ & $\begin{array}{l}\text { Headache } \\
\& \\
\text { Feeling } \\
\text { feverish } \\
\text { Cold and } \\
\text { Headache }\end{array}$ & Prescription \\
\hline & & A38 & $\begin{array}{l}\text { PCM + } \\
\text { Rantac }\end{array}$ & $\begin{array}{l}500 \\
\mathrm{mg} \\
150 \\
\mathrm{mg} \\
\text { given } \\
\text { Stat }\end{array}$ & $\begin{array}{l}1 \text { Day } \\
\text { (Once) }\end{array}$ & $\begin{array}{l}\text { Fever, } \\
\text { Body } \\
\text { Pain }\end{array}$ & Prescription \\
\hline $14^{\text {th }}$ day & 00 & \multicolumn{6}{|l|}{ Nil } \\
\hline
\end{tabular}




\section{References:}

${ }^{1}$ https://www.worldometers.info/coronavirus/countries-where-coronavirus-has-spread/

2 Symptoms of Coronavirus, Centre for disease control and prevention, https://www.cdc.gov/coronavirus/2019-ncov/symptoms-testing/symptoms.html

${ }^{3}$ https://www.covid19treatmentguidelines.nih.gov/overview/

${ }^{4}$ Esakandari, Hanie et al. "A comprehensive review of COVID-19 characteristics." Biological procedures online vol. 22 19. 4 Aug. 2020, doi:10.1186/s12575-020-00128-2

${ }^{5}$ Suranga L Senanayake, Drug repurposing strategies for COVID-19, Future Drug Discovery, vol. 2, March, 2020

${ }^{6}$ Mithun Rudrapal, Shubham J. Khairnar and Anil G. Jadhav, Drug Repurposing (DR): An Emerging Approach in Drug Discovery, intechopen, July, 2020, https://www.intechopen.com/online-first/drug-repurposing-dr-an-emerging-approach-indrug-discovery

${ }^{7}$ K.D Sharma, et al. A Clinical Trial of Ayush 64 ( A coded antimalarial medicine ) in cases of malaria, JRAS, Vol II, No-4.

${ }^{8}$ M.V.Chari et. al. A double blind Clinical trial with Ayush 64 an Ayurvedic Drug in P. Vivax Malaria, JRAS, vol. Vi, No.1, 3 \& 4 pp-105-116

${ }^{9}$ D. Bhatia, Role of Ayush-64 in Malaria Epidemic, JRAS Vol. XVII, No. 1-2, 1997, pp-71-76

${ }^{10}$ T.Seshagiri Rao et.al. Clinical Trail of Ayush 64 in Sleepada, JRAS Vol.III,No.1 \& 2, pp-912

11 An epidemiological Survey on Microfilaraemia in the Villages around Bhubaneswar with Therapeutic Effect of Ayush 64, JRAS Vol XII, No. 1-2, pp- 33-40.

${ }^{12} \mathrm{P}$ N Pandey and Prem Kishore, Effect of Ayush 64 and Saptaparnaghana Vati on Microfilaraemia., JRAS Vol XII, No 3-4, pp- 145-150.

${ }^{13}$ AYUSH 64 , A new Ayurvedic Anti-Malarial Compound, Central Council for Research in Ayurveda \& Siddha (CCRAS) 1987.

${ }^{14}$ K. D. Sharma et.al. A Clinical Trial of UAyush 64" (A Coded Antimalarial Medicine) in Cases of Malaria. Jour. Res. Ay. Sid., Vol. II. No. 4

15 D.Bhatia. Role Of Ayush- 64 In Malaria Epidemic. JR.A.S. Vol. XVIII, No. 1-2, (J997)pp.71-76 252 M.V. Chari et. Al. A Double Blind Clinical Trial With Ayush-64 an Ayurvedic Drug in P. vivax Malaria. Jour. Res. Ay. Sid. Vol. VI. No.1, 3 \& 4 pp. 105-116

${ }^{16}$ M.V. Chari et. Al. A Double Blind Clinical Trial With Ayush-64 an Ayurvedic Drug in P. vivax Malaria. Jour. Res. Ay. Sid. Vol. VI. No.1, 3 \& 4 pp. 105-116 
${ }^{17}$ Manohar S. Gundeti et al.,AYUSH 64, a polyherbal Ayurvedic formulation in Influenza like Illness: results of a pilot study,Journal of Ayurveda and Integrative Medicine,2020.

${ }^{18} \mathrm{https} / / / \mathrm{www}$. ayush.gov.in/docs/faq-covid-protocol-Revised.pdf

${ }^{19}$ Vagbhata. Ashtang Hridaya. In: Paradkar H, editor. Nirnay Sagar Press. 6th ed. Bombay: Pandurang Jiwaji; 1939

${ }^{20}$ Manohar S. Gundeti et al.,AYUSH 64, a polyherbal Ayurvedic formulation in Influenza like Illness: results of a pilot study,Journal of Ayurveda and Integrative Medicine,2020.

${ }^{21}$ Whitehead AL, Julious SA, Cooper CL, Campbell MJ. Estimating the sample size for a pilot randomized trial to minimize the overall trial sample size for the external pilot and main trial for a continuous outcome variable. Stat Methods Med Res. 2016 Jun;25(3):1057-73. doi: 10.1177/0962280215588241. Epub 2015 Jun 19. PMID: 26092476; PMCID: PMC4876429.

${ }^{22}$ Chinmay S. P. et al., Outcome of ivermectin treated mild to moderate COVID 19 cases: a single centre, open label, randomized controlled study, IMC J Med Sci 2020, 14(2):002

${ }^{23}$ Tang, Wei et al. "Hydroxychloroquine in patients with mainly mild to moderate coronavirus disease 2019: open label, randomised controlled trial." BMJ (Clinical research ed.) vol. 369 m1849. 14 May. 2020, doi:10.1136/bmj.m1849

${ }^{24}$ Lou, Yan et al. "Clinical Outcomes and Plasma Concentrations of Baloxavir Marboxil and Favipiravir in COVID-19 Patients: An Exploratory Randomized, Controlled Trial." European journal of pharmaceutical sciences : official journal of the European Federation for Pharmaceutical Sciences vol. 157 (2021): 105631. doi:10.1016/j.ejps.2020.105631

${ }^{25}$ Dongyuan Wang, Zigang Li, Yihui Liu, An overview of the safety, clinical application and antiviral research of the COVID-19 therapeutics, Journal of Infection and Public Health, Volume 13, Issue 10, 2020, Pages 1405-1414, ISSN 18760341,https://doi.org/10.1016/j.jiph.2020.07.004.

${ }^{26}$ Siemieniuk, Reed Ac et al. "Drug treatments for covid-19: living systematic review and network meta-analysis.” BMJ (Clinical research ed.) vol. $370 \mathrm{~m} 2980$.

${ }^{27}$ Jomah, Shahamah et al. "Clinical efficacy of antivirals against novel coronavirus (COVID19): A review." Journal of infection and public health vol. 13,9 (2020): 1187-1195. doi:10.1016/j.jiph.2020.07.013. In severe or mild cases of COVID 19 Lopinavir/Ritonavir showed no benefit beyond standard care.

${ }^{28}$ Patricia R. et al. Early use of nitazoxanide in mild Covid-19 disease: randomised, placebocontrolled trial, European Respiratory Journal 2020; DOI: 10.1183/13993003.03725-2020

${ }^{29} \mathrm{WHO}$, Criteria for releasing COVID-19 patients from isolation 
https://www.who.int/news-room/commentaries/detail/criteria-for-releasing-covid-19-patientsfrom-isolation

${ }^{30}$ Jonathan P Rogers et al. Psychiatric and neuropsychiatric presentations associated with severe coronavirus infections: a systematic review and meta-analysis with comparison to the COVID-19 pandemic, Lancet Psychiatry 2020; 7: 611-27.

${ }^{31}$ WHO, Criteria for releasing COVID-19 patients from isolation

https://www.who.int/news-room/commentaries/detail/criteria-for-releasing-covid-19-patientsfrom-isolation

32 Bongiovanni, Marco et al. "The dilemma of COVID-19 recurrence after clinical recovery." The Journal of infection, S0163-4453(20)30553-3. 15 Aug. 2020, doi:10.1016/j.jinf.2020.08.019

${ }^{33}$ Kile Green, What is the role of imaging and biomarkers within the current testing strategy for the diagnosis of Covid-19?, The Centre for Evidence-Based Medicine, April 2020

${ }^{34}$ Rodriguez-Morales AJ, Cardona-Ospinaa JA, Gutiérrez-Ocampoa E, et al; Latin American Network of Coronavirus Disease 2019-COVID-19 Research (LANCOVID-19). Clinical, laboratory and imaging features of COVID-19: A systematic review and meta-analysis. Travel Med Infect Dis. Published online March 13, 2020. DOI: 10.1016/j.tmaid.2020.101623

${ }^{35}$ Lippi G, Plebani M. Laboratory abnormalities in patients with COVID-2019 infection Clin Chem Lab Med. Published online March 3, 2020. DOI: 10.1515/cclm-2020-0198.

${ }^{36}$ Dongyuan Wang, Zigang Li, Yihui Liu, An overview of the safety, clinical application and antiviral research of the COVID-19 therapeutics, Journal of Infection and Public Health, Volume 13, Issue 10, 2020, Pages 1405-1414, ISSN 1876-0341, https://doi.org/10.1016/j.jiph.2020.07.004.

${ }^{37}$ Jomah, Shahamah et al. "Clinical efficacy of antivirals against novel coronavirus (COVID19): A review." Journal of infection and public health vol. 13,9 (2020): 1187-1195. doi:10.1016/j.jiph.2020.07.013.

${ }^{38}$ Lan Chen et al. Efficacy and safety of chloroquine or hydroxychloroquine in moderate type of COVID-19: a prospective open-label randomized controlled study, Preprint from medRxiv, 22 Jun 2020

DOI: $10.1101 / 2020.06 .19 .20136093$

${ }^{39}$ Arunmozhimaran Elavarasi et al. Chloroquine and Hydroxychloroquine for the Treatment of COVID-19: a Systematic Review and Meta-analysis, Journal of General Internal Medicine volume 35, pages3308-3314(2020). 
${ }^{40}$ Puthiyedath, R., Ayurvedic clinical profile of COVID-19 - A preliminary report. Journal of Ayurveda and integrative medicine, S0975-9476(20)30039-5. Advance online publication. https://doi.org/10.1016/j.jaim.2020.05.011

${ }^{41}$ Rastogi, S., Pandey, D. N., \& Singh, R. H. (2020). COVID-19 pandemic: A pragmatic plan for ayurveda intervention. Journal of Ayurveda and integrative medicine, S09759476(20)30019-X. Advance online publication. https://doi.org/10.1016/j.jaim.2020.04.002

${ }^{42}$ S. Bhargava et al, Sci Pharm. Antipyretic Potential of Swertia chirata Buch Ham. Root Extract $2009 ; 77 ; 617-623$

${ }^{43}$ G. Praveen Bhat et.al., in vitro antimalarial activity of extracts of three plants used in the traditional medicine of india, Am. J. Trop. Med. Hyg., 65(4), 2001, pp. 304-308 53

${ }^{44}$ Arif $\mathrm{T}$ et. Al. In vitro and in vivo antimicrobial activities of seeds of Caesalpiniabonduc (Lin.) Roxb. J Ethnopharmacol. 2009 May 4;123(1):177-80. doi: 10.1016/j.jep.2009.02.040. Epub 2009 Mar 9

${ }^{45}$ Kumar RS, Narasingappa RB, Joshi CG, Girish TK, Danagoudar A. Caesalpinia Crista Linn. Induces protection against DNA and membrane damage. Phcog Mag 2017;13:S250-7. 40

${ }^{46}$ Dhruti Mistry \& Meonis Pithawala (2017): Protective effect of Alstonia scholaris Linn. R. Br. Against Bleomycin induced chromosomal damage in cultured human lymphocytes, in vitro, Drug and Chemical Toxicology, DOI: 10.1080/01480545.2017.1329316 Clinical studies

$47 \mathrm{Hu}$ Tian-Yong et.al. Anti-inflammation action of xanthones from Swertia chirayita by regulating $\mathrm{COX}-2 / \mathrm{NF}-\kappa \mathrm{B} / \mathrm{MAPKs} / \mathrm{Akt}$ signaling pathways in RAW 264.7 macrophage cells. Phytomedicine 55 (2019) 214-221

48 Manjeshwar Shrinath Baliga. Review of the Phytochemical, Pharmacological and Toxicological Properties of Alstonia Scholaris Linn. R. Br (Saptaparna). Chin J Integr Med. 2011. DOI: $10.1007 / \mathrm{s} 11655-011-0947-0$

49 Sies, H., 1996. Antioxidants in Disease, Mechanisms and Therapy. Academic Press, New York

${ }^{50}$ So-Yeun Woo, Nwet Nwet Win, Wyine Myat Noe Oo, Hla Ngwe, Takuya Ito, Ikuro Abe, and Hiroyuki Morita. Viral protein R inhibitors from Swertia chirata of Myanmar. J. Biosci. Bioeng. 2019; 128(4):445- 49, https://doi.org/10.1016/j.jbiosc.2019.04.006

${ }^{51}$ Verma H, Patil P R, Kolhapure R M, et al. Antiviral activity of the Indian medicinal plant extract, Swertia chirata against herpes simplex viruses: A study by in-vitro and molecular approach. Indian J Med Microbiol 2008;26:322-326

${ }^{52}$ Dhar ML, Dhar MM, Dhawan BN, Mehrotra BN, Ray C. Screening of Indian plants for biological activity: I. Indian J Exp Biol, 6(4), 1968, 232-247. 
${ }^{53}$ Shukla S, Mehta A, John J, Mehta P, Vyas SP, Shukla S. Immunomodulatory activities of the ethanolic extract of Caesalpiniabonducella seeds. J Ethnopharmacol. 2009 Sep 7;125(2):252-6. doi: 10.1016/j.jep.2009.07.002. Epub 2009 Jul 14.

${ }^{54}$ Dhar ML, Dhar MM, Dhawan BN, Mehrotra BN, Ray C. Screening of Indian plants for biological activity: I. Indian J Exp Biol, 6(4), 1968, 232-247.

${ }^{55}$ Amit Gupta at.al. Immunomodulatory activity of biopolymeric fraction RLJ-NE-205 from Picrorhizakurroa. International Immunopharmacology, 2006; 6(10):1543-9. DOI: 10.1016/j.intimp.2006.05.002

56 M.L.Sharma, C.S.Rao, P.L.Duda. Immunostimulatory activity of Picrorhizakurroa leaf extract. Journal of Ethnopharmacology. 1994;41(3): 185-192. https://doi.org/10.1016/03788741(94)90031-0

${ }^{57}$ Hussain A, Shadma W, Maksood A, Ansari SH. Protective effects of Picrorhizakurroa on cyclophosphamide-induced immunosuppression in mice. Pharmacognosy Res. 2013 Jan;5(1):30-5. doi: 10.4103/0974-8490.105646. PMID: 23598922; PMCID: PMC3579017.

58 Shukla Shruti. In Vivo Immunomodulatory Activities of Aqueous Extract of Caesalpinia Bonducella Seed, Pharmaceutical Biology (Formerly International Journal of Pharmacognosy). 2010;48(2):227-230

${ }^{59}$ T.A. Vaidya Jadavaji (Ed.), Charaka Samhita of Acharya Charaka, Chikitsa Sthana, Jvara chikitsa, 3rd Chapter, Verse 142-143, (5th ed.), Chaukambha Sanskrit Sansthan, Varanasi (2001), p. 409

${ }^{60}$ Sushruta. Sushrutasamhita. In: Acharya JT, editor. Sushrut Samhita-Dalhan Tika. Varanasi: Chaukhamba Surbharati Prakashan; 2018. p. Sutra Sthana Verse 40/5 ,186.

61https://www.cdc.gov/coronavirus/2019-ncov/hcp/clinical-guidance-managementpatients.html 